\title{
'Men Alone' as Outlaws? - Hyde's 'Starkie', Lee \& Lee's Porcello, \& Mulgan's Johnson
}

\section{JOHN C. ROSS}

The notion of 'criminal heroes', in the title originally submitted for the conference paper, offers some intriguing ironies, yet in investigating the protagonists, 'Starkie', aka James Douglas Stark, in Robin Hyde's Passport to Hell (1936), Albany Porcello, in John A. Lee's The Hunted (1936), and Johnson, in John Mulgan's Man Alone (1939), I came to see them rather as outlaws. ${ }^{1}$ The linking of the three works, and their authors, is neither arbitrary nor merely a matter of close dating: between March 1936 and June 1939 Hyde and Lee were carrying on a lively correspondence about their similar literary and social concerns, Hyde in 1935 had evidently been the author of a sympathetic review of Lee's first novel, Children of the Poor (1934), and may well have been influenced by it (at least in its providing her with a precedent); and also, as will be shown below, Mulgan's novel doubtless owed much to Lee's unpublished earlier writing. ${ }^{2}$

While there is a partial overlap in application between the concepts of 'criminal' and 'outlaw', exploring the tensions in the distinction between 'outlaw' and 'criminal', in each novel, has become a useful approach for this article. The principal concern here is with extending this distinction into an analysis of the constructions of the kinds and degrees of outlaw status of the three works' central characters. In each case, one can see both an objective and a subjective dimension. Objectively, it can be said that an outlaw is a person existing and acting outside the compass of the rule of law, and the justice system. A criminal, in the narrower sense, is a person convicted as guilty of having committed one or more serious crimes, hence encompassed by the system (a person inscribed as a criminal, but on the run, either as not yet arrested and convicted, or else as an escaper, would also be, for the meantime, an outlaw). Subjectively, there is the factor of perception - how a person is perceived by others, or by him/herself. One may commit an act that society would condemn as a crime, yet defy the inscription of oneself as a criminal, and choose to not submit to the regime of arrest, trial, and punishment, for the sake of the survival of one's core identity, either as an affirmation of its integrity, or else as a rebellious gesture by means of which a changed self is constituted.

The systems of power and law, which define criminality or outlawry, may themselves be contentious. To the extent that they are essentially dictated and controlled by the current wealthand-power elite, operating to protect and further their personal interests and those of their own class, or clique, and, where the population is multi-ethnic, of their own ethnic group, very discrepant perceptions may well arise as to whether the legal system in force is ethically legitimate, or else radically unjust - arbitrary, inequitable, and blatantly biased. Hence, alongside a host of present-day and recent examples, one can perceive the abiding glamour of the archetypal mythic outlaw Robin Hood and his band of merry men and maids in Sherwood Forest, robbing the rich in order to help the poor, as deriving in part from the perception that they were native English, whereas the wielders of national and regional state and judicial power were rapacious, cruel, oppressive Anglo-Normans.

Factors which enable a person to be perceived, relatively sympathetically, as an outlaw rather than a criminal can be usefully illustrated in the case of Kimble Bent, who deserted from the $57^{\text {th }}$ Regiment of Foot in southern Taranaki on 12 June 1865, and joined up with the Hauhau, 
remaining with them during the warfare in that region, and within the Māori world for nearly all of the rest of his life. Doubtless he was seen at the time by the European authorities as a renegade, a traitor, guilty of involvement in, or, at least, support of, criminal rebellion and savage atrocities. Contrariwise, it can be said that since he was not British but an American, and moreover (like Starkie) one-quarter First Nations, in his case Musqua Indian, he was not a traitor to his own nation, or ethnicity. Within his regiment, which he hated and had previously tried persistently to get his discharge from, a sadistic corporal had got him brutally flogged for a minor act of insubordination. While among the Hauhau, he never fired a shot during the fighting. It can also be said that the warfare in which he was involved arose because of the means by which Māori were being deprived of their land, for the benefit of white settlers, means which were often grossly unjust, unscrupulous, racially biased, and imposed by force of arms, so that Māori armed resistance to them was not unjustifiable. Moreover, during this warfare, the much-sensationalized savagery perpetrated by the Hauhau was matched by the savagery and barbarity of the Government forces, and especially of the kupapa Māori led by Major Kemp, Kepa Te Rangihiwinui, less bizarrely extreme, yet perpetrated on a larger scale, including rampant headhunting for the sake of bounty-payments. ${ }^{3}$

On five counts, then, Bent can be seen as an outlaw, rather than a criminal, and a fairly sympathetic figure: from the start, he was already in some ways an outsider, as a man of alien and mixed ethnicity, and actively as well as in his own eyes discriminated against; his lifesituation, being held in the regiment against his will, was already harsh and oppressive; his breaking away from it, in deserting, was triggered by a traumatic event, the flogging; what he subsequently did was not substantially immoral or criminal; and the authority-regime to which he opposed himself was itself arbitrary, brutal and perverse. More broadly, his career as a certain kind of Pakeha-Māori is in itself of great interest, but addressing that belongs within a different kind of discussion, as can be found in our book The Lonely and the Alone.

All three works being addressed here came out of the hard years of the 1930s Great Depression, which caused great hardship among the less fortunate, bitter social divisions, hunger, and in April-May 1932 riots, and harsh confrontations between demonstrating unemployed workers and police, or the hated special constables, in Auckland, Wellington and Christchurch, and the repressive prosecutions that followed (the two books published in 1936 would have been written in the previous year, while conditions were still hard). The events of Passport to Hell (pre-war) and in The Hunted (along with its prequel Children of the Poor) are however set in the late 1890s through to 1914, in the period of slow recovery from the 1880-95 Long Depression, within which the growth in relative prosperity was quite uneven, with the real value of workingclass wages being eroded by inflation. A smouldering sense of social injustice coupled with misplaced socialist optimism led to a series of strikes, from 1906 through to 1913, that mostly failed in their aims; and after the displacement of the Liberal regime by the Reform Party government in July 1912, they were beaten down with vindictive brutality, epitomized by the bashing-up of strikers by mobs of farmers' sons enlisted as special constables, 'Massey's Cossacks. ${ }^{4}$ Seen from the bottom up, these clashes engendered a bitter memory of class hostility and of the forces of law and order as agents of state repression, revived in the 1930s. Hence some romantic appeal could attach to individuals who evaded, resisted, or actively rebelled against, being deferentially conformist, submissive to authority, and resigned to social victimhood.

Journal of New Zealand Studies NS13 (2012), 128-143. 
'Bronze Outlaw' (as opposed to the originally thought-of 'Crime Sheet') was Robin Hyde's chosen title for her quasi-biography of Starkie that was re-named Passport to Hell, at the initiative of the publishers. ${ }^{5}$ Iris Guiver Wilkinson, who adopted Robin Hyde as her nom-deplume, was herself socially aberrant, as a full-time female writer, as the mother of a hidden illegitimate son, and as a person living in a kind of halfway house between the worlds of the sane and the insane. ${ }^{6}$ Hence, the appeal of the figure of the outlaw is bound to have had a special resonance for her (she wrote of herself as 'Outlaw' in a verse fragment written in 1935), as well as having, for her potential readers, much to do with a sense that such figures exhibit, to an exceptional degree, certain qualities we might still like to believe are (or, at least, have been) typical, or even archetypal, of New Zealanders. ${ }^{7}$

This notion is prompted by an observation by D. I. B. Smith, in his introduction to the 1986 edition of Passport to Hell, that Starkie, 'although a seemingly unique figure . . . was also in some senses the quintessential colonial soldier', in that in the 1914-18 War 'troops from the Dominions were noted both for their magnificent fighting qualities and for their casual attitude towards discipline. ${ }^{8}$ These qualities - physical and mental toughness, resilience, instinctive and unrelenting belligerence, the capacity to exercise individual initiative with great potency, acting, if need be, alone - made him an outstandingly effective battlefield soldier who survived Gallipoli and the Western Front and carried out actions that would have earned more orthodox men a chest-full of medals. In his case, however, these very qualities, along with an uninhibited disregard for, or active hostility towards, established authority and conventional military and social discipline, repeatedly got him into trouble away from the front-line, especially when drunk, leading to nine court-martials, resulting in sundry lesser punishments, and eventually, in a spell in a barbarically harsh military prison. That Starkie as informant, and Hyde as author, both exaggerated his youthfulness implicitly lessens his culpability. ${ }^{9}$ In this respect, as in some others, Hyde's narrative is not so much biography as story, with its own organic authenticity, and merits being accepted as such, regardless of its occasionally demonstrable factual inaccuracies. The essential authenticity of Hyde's rendition of Starkie's account of a World War One soldier's experiences was warmly acknowledged by men who had shared them. ${ }^{10}$

In literary kind, Passport to Hell is sui generis. It is as Hyde herself wrote, "not a work of fiction', but her rendition of the earlier part of the man's own life-story as he had told it to her, and she added that her object in writing the book was not to portray the outside world looking at Starkie, but to portray Starkie looking at the outside world. After all, that outside view, especially of any person estranged from society by lawlessness, sickness or poverty, means so little. If I have any ambition as a prose writer, it is to write from the inner centre of what people think, hope and feel, and of that Interpreter's House, those set in authority over us know curiously little, because they have no humility'. 11

Yet even this does not do justice to the work's hybridity. It does at least partly convey the authorial persona looking at Starkie, and in some places interpolating her own interpretations and reflections. It is substantially removed from objective biography, with the subject not the person James Douglas Stark, but Starkie, a known 'character', even in his own eyes; and the narrative is his 'story', as told (and re-told) by himself, and then mediated by the narrating persona, who may be conceived of as present throughout as implied interlocutor.

Following the book's first section, 'Introduction to Starkie', where the narrative is in the first 
person, with the authorial persona visiting the man in the narrating present, the narrative is mainly rendered in the third person, yet is in the first person in Chapters 9 ('In which Starkie speaks for himself') and 15, in most of Chapters 17 and 18, and in brief passages elsewhere, with Starkie himself ostensibly telling his own story, shifting between past and present tenses. Here the reader has no way of knowing to what extent his own words are being presented verbatim, or whether, and if so, to what extent, his voice has been adopted by Hyde, as a kind of ghostwriter. Within the portions of third person narration the degrees of authorial distancing from the character's centre of consciousness are not so much layered as quite fluid.

In Chapter 1, entitled 'Making of an Outlaw', Starkie is seen as from birth set apart as an outsider by his pigmentation, his father reputedly pronouncing him, at first sight, 'Black as the ace of spades', although Hyde considers him as being, apart from his black eyes and hair, of 'a very seemly bronze colour'. ${ }^{12}$ In largely monochrome Southland, where the only others not 'white' or 'yellow', but in the third category, 'black', at that time, were a few Maori, who 'smiled and lounged in the easy background of life', his skin-tone made him conspicuous, and a potential target for prejudice, as a 'black bastard'. ${ }^{13}$ Hyde states outright that his father Wylde (properly, Wyald) Stark was 'a Delaware Indian from the regions of the Great Bear Lake' and his mother Spanish, 'born in Madrid', although both were clearly of more complex origins. ${ }^{14}$

Whether partly by heritage or wholly by temperament, even as a boy he was wayward, wilful, not conditioned into social conformity, or compliance with disciplinary codes, and endowed with a primary impulse towards fight rather than flight. As a schoolboy, he was a chronic truant, much preferring to wander off to some muddy stream to catch eels. Still, the narrator stresses that 'there was no manner of real frightfulness about his escapades. He was simply schoolboy - large, intractable, cheerful, and unimpressionable schoolboy.' ${ }^{15}$ She shows him becoming an incipient outlaw not by deliberately breaking social conventions or laws but by disregarding them, unconstrained by any fear of the consequences of obeying his impulses, moving on from school to school, with his 'reputation as an outlaw' preceding him. ${ }^{16}$ Even the Burnham Industrial School (such a horror to John A. Lee), to which he would be consigned for indulging an 'acute form' of the boyish temptation, at a certain 'dread age', to chuck stones at telegraph-pole insulators, was for him, ironically, simply one more institution 'he disliked ... as he disliked every other form of authority set over him, but not much worse than the other abodes of learning, and not nearly so keenly as he hated the Marist priest' in his previous school. ${ }^{17}$

Circumstances and temperament conspired to get him into further trouble with the forces of law. Before the 1914-18 War, having beaten up a special constable, in an act of retaliation, during the 1913 strike, and then stolen a bicycle, as you would, to get away from that situation, he spent a year in prison, with hard outdoor labour, and periods of brutal special punishment. At the end of this ordeal, he returned to Invercargill, as the only place he could call home, yet his family-members were by then either dead or dispersed, and the local police made it all too clear that he was a marked man. With the war started, and seeing no tolerable alternative ahead of him, he enlisted in the army, even though he was still officially too young, and went off to Trentham Camp.

Once there, he found himself a second family, in the group of seven 'giants' he joined in with in D Line, Tent Eight, and a role within it as dogsbody, scapegoat, mascot. When they all accepted three days' C.B. (confined to barracks), rather than dumping on him for stealing straw 
bedding from another tent, 'Starkie decided that he was going to like the War'. ${ }^{18}$ However, the first of them to die would be killed by a sniper within their first few days ashore at Gallipoli. Shifted on to France, within a couple of days of arrival in the trenches at Armentières, three of them were seriously wounded, and so were two more soon after, and a youngster who had taken over the mascot role killed, in a raid gone disastrously wrong. By the end of the Battle of the Somme, all but one of them were either dead or seriously wounded, and he discovered the body of his brother George, the only biological-family-member he was bonded to, torn in two parts by a shell. Partially unhinged by fury and grief, he became a ferocious killer for the remainder of the battle. Thereafter, he could find comfort only in drunkenness, and bashing a corporal on the nose during a drunken mass punch-up got him into a state of even worse official criminality than his many previous misdemeanours had brought about. When caught up with, ten months later (following a period in which tens of thousands of men were killed horribly), this affront remained unforgiven, and he was sentenced for two years' hard labour at the sadistically brutal military prison at Le Havre.

From early on, he had come to see autocratic schoolteachers, police, judges, and prison guards as 'the villains', with officious and bullying military police and army corporals then joining this obnoxious mob. ${ }^{19}$ The NCO guards and their major at the Le Havre prison proved the worst of 'the Villains' and the epitome of villainy. ${ }^{20}$ All the same, their regime, devised to utterly crush the spirit of recalcitrant prisoners, did not break his, and instead he went to extreme lengths, including violence and risking death, to escape from them. Much of his wartime experience had been traumatic enough, but it was the trauma of the Le Havre prison experience that launched him into his most extreme outlawry, as he made his escape by ship, and moved here and there within France by train or truck, masquerading successively as an American infantryman, a Negro Labour Corps dockworker, a ship's trimmer, an Australian Light Horse Trooper, and a kilted Scotsman, mingling with deserters, stragglers, 'waifs and strays'. ${ }^{21}$

Still, both because it was less hopelessly dangerous, and because of a kind of homesickness, he found his way back to his own unit, 'Otago Fourth'. ${ }^{22}$ Yet even here, with the last of his close mates vanished, he was nothing but a 'hanger-on', 'nobody's soldier', with his presence silently tolerated, yet no pay-book, no proper entitlement to rations, no number, no sure prospect of a passage back home at the end of the war, but rather of being shunted off to some military prison. ${ }^{23}$ It was from within this limbo condition that he volunteered to take on a duel with a German sniper. Three thousand men were watching, but he did it alone, as narrated in a sequence of intense authorial identification with his consciousness in the present.

Five hundred yards from the British trench the grass is high enough to reach over a man's head if he lies very flat. Rank grass, keen with the smell of winter. Inch by inch now. My father was a Delaware Indian, and I'm playing at snake in the grass. Safely under the wire, and there's the old strongpoint straight ahead. The point is, where's the sniper? In there, or waiting in the shell-crater to pot a man in the back ? $^{24}$

He crawled to 'a range of six yards', and suddenly the sniper shot him 'through the right lung,' yet in spite of this he found the strength to throw his Mills bomb and kill the man, and to struggle enough of the way back to the British trenches for his fellow soldiers to rescue him 
(Hyde's notes record that remarks overheard as he was carried in included: 'Is that the Outlaw? Isn't he dead yet?). ${ }^{25}$ Even then he remained a rebel, and remarkably tough, both of body and will, in stubbornly refusing to comply with others' expectations: 'I'm — if I die!' ${ }^{26}$ Having come so close to death, and been dispatched to the Brockenhurst military hospital in England, he was accepted back into the fold, for the meantime, an outlaw no longer.

Later on, having sufficiently healed from his wound, he rejected official efforts to invalid him back to New Zealand, or to employ him to train others (at Sling Camp he took up residence in 'the clink' as the 'one quiet place' where he wouldn't be bothered with early roll-call, or drill, or the unreasonable expectation that he should salute anyone), and insisted on getting back to his community of fighting infantry, as the only home he still had. ${ }^{27}$ Once there, he got badly wounded again, yet again would survive. Later still, back in New Zealand, convalescing at the near-deserted Trentham Camp, and thereafter, as recounted in the sequel, Nor the Years Condemn, his life would be punctuated by episodes of petty crime, and spells of gaol-time.

He was still intermittently getting into such trouble during the period Hyde had the conversations with him on which her two biographical works were based; she had encountered him first in 1931 when, as a journalist, she was visiting inmates of Mount Eden Prison. Her portrayal of Starkie as 'bronze outlaw' has captured something of the appeal of a transgressive personality who had managed to survive, both in body and spirit, the harshest of times without ever internalizing the norms of submission or deference to legalized authority, or inhibitions about exceeding its parameters. Generally, her narrative reports his attitudes and his simply doing what he does, with a great deal of relish and wry humour, in a book which she herself considered, in 1935 , 'certainly the best, in prose -- not uneven or rambling', of her works up to that time. ${ }^{28}$

Hyde wrote to John A. Lee, on 29 May 1936, 'I think it will be a considerable jar for the public to have "The Hunted" and "Passport to Hell" smiling at one another from opposite corners of Whitcombe and Tombs?' Both works had been published in London, with inevitable time-lags between completion, acceptance, publication, and appearance in New Zealand bookshops; hers appeared in May, and his evidently did so at around about the same time. ${ }^{29}$ Both provide very discomforting views of New Zealand society and its institutions as seen from the bottom up, adopting the viewpoint of its outcasts.

Discrepancies between life and 'story' figure intriguingly in the relationships between Lee's own earlier life-experiences and those he gives to his character Albany Porcello in his novels Children of the Poor (1934) and The Hunted (1936), with his own experiences, as Janet Frame would put it, taken to 'Mirror City', transformed there, and brought back again as imaginativelycoloured and artistically shaped fictions. ${ }^{30}$ The former deals with happenings and dynamics in the character's earlier life that culminate in his judicial consignment to the Burnham Industrial School; the latter deals with his experiences there, or subject to its custody, and his successive attempts to escape, escalating in degrees of success, culminating in his eventual final getaway.

John Albert Alexander Lee, born in 1891 into an impoverished Dunedin family, leaving school early and unable to hold down a job, was arrested twice for theft in 1906, deemed by a judge to be 'incorrigible', and consigned to the Burnham Industrial School, and its authority, till the age of twenty-one. This first phase of his life provided the basis for Children of the Poor. The years he spent at this reformatory, his repeated attempts to run away from it, his experiences when sent out to work, and his eventually successful absconding, provide the grounds for The 
Hunted. The next phase, of finding work here and there, but still on the run from the law, and of moving around in both islands, until he was arrested, and consigned to an adult prison for a year, for several minor offences, is recalled in straightforward autobiography in Delinquent Days (1967). He writes these works from the perspectives of a Labour Party Member of Parliament, by 1936 a prominent member of the first Labour government, urging compassion and understanding, yet able to admit, in the third of them, that it was just as well that he had got caught when he did, before the imperatives of surviving as an outlaw drew him into more serious criminality.

Turning then to The Hunted, it is a given from his first appearance that the character Albany Porcello is a spirited boy whose previous life has been blighted by family poverty, and by a social milieu and structure that are prejudicially marginalizing and harsh towards the poor. His level of criminality has been quite minor, and largely a consequence of circumstances, and the response to it by the legal regime disproportionately punitive. On the train taking him to Burnham, he is already consumed with an inward drama, with his outward 'scowl' reflecting his temperament as 'a fighter':

Already the boy had conjured up an antagonist. That antagonist was the law with which he could see himself going to war. The scowl merely signified the determination with which he visioned himself going on to win and taking the enemies' blows. . . . [He] had decided to fight his way free at first opportunity. . . . And already he could see himself running, pursued by the avenging law, by horse and foot, thrown upon the lasting quality of his limbs and wits, an outlaw. ${ }^{31}$

Much of the action of the novel amounts to the playing-out of that 'determination'. The regime at the Burnham Industrial School, to which he is consigned, is excessively authoritarian, oppressive, and punitive towards the slightest breaches of discipline. While the Manager may not himself be a sadist, he condones the exercise of sadistic brutality by certain members of his staff. Albany's inward resistance to this crushing denial of individual freedom reinforces his desire to run away, even though it leads to the anxieties of the hunted outlaw, and the risk of further floggings.

The novel's most imaginatively alive sequence is that which covers his fourth escape, whereby he stays free for a whole month, as a boy-outlaw, before being recaptured. The author within the novel is usually a fairly orthodox omniscient narrator, yet here he often enters dramatically into Albany's consciousness, for example, at the point where the boy comes across a rabbiter's hut, stocked with food-supplies, within a small pine plantation, and makes himself a lavish mid-day meal of bacon, fried potatoes, and hard biscuit and jam, washed down with plenty of billy tea.

His hands blackened with pan and billy smut, his face sweated from the heat of pine and the warm liquids he swallowed. Yes. He would stay for at least a day. He found a heap of cheap novels by the side of the wire-netting bed, a candle or two for night reading. Perhaps he would stay for a few days. [He goes on to explore the edges of the plantation.] The day advanced and the evening came, and no one came near him. The world was too much 
concerned with its own business. Yes. He would stay a few days in the shelter. ${ }^{32}$

This 'yes' is narrower in scope than Molly Bloom's at the end of Joyce's Ulysses, yet it likewise conveys a mind arriving at decision, and at a strong affirmation of its own vitality. There is a free moving in and out of the character's centre of consciousness, with passages of free indirect discourse. The narration can convey not only the concrete objective detail of the 'heap of cheap novels', the 'wire-netting bed' and the 'candle or two', but also the mind registering these details.

Still, the exhilaration of the moment will give way to anxiety (the man whose supplies he is eating up is bound to turn up sooner or later), and in his moving on southward he gets trapped and re-arrested. At the end he does escape to a kind of freedom, yet it remains the freedom of the outlaw: 'The shadow of the law was at his shoulder. In the quiet moments as he sat or lay [sic] himself down he wondered where the net was set to trap his erring feet. His body was free but his mind knew the insecurity that dominates the life of all that is hunted. For fear is of the soul and not of the world about. 33

The hunted human outlaw becomes here one with wild creatures, endlessly alert for the approach of birds or beasts of prey. All the same, in Lee's 'Preface' to this novel, he writes that he is 'glad' of his own experience of having 'been hunted', firstly, because he learned from it a kinship with all of threatened humanity, and secondly, because being hunted brought kinship with open spaces. 'I know the majesty of towering moonlit Alps seen from sea-level plains. I know their morning splendour when wraithed in cloud and mist. I know the music of skylark long after the singer has winged to heaven. I have slept by rivers when hot winds dissolved snow, so that I lay down by trickle and awakened by torrent. ${ }^{, 34} \mathrm{He}$ goes on further in this vein, and ends by indicating that his motive in writing has been to induce fellow-feeling and understanding among his safe and secure readers for the less fortunate and discriminated against.

This direct 'kinship' with nature is matched in Delinquent Days by Lee's equally intense experience of the virgin rainforest of the southern King Country area, rendered more potent by the heightened alertness of the fugitive outlaw. After a few years doing casual farm work in Otago and Southland (slipping away pay-less whenever a policeman came by), he headed off to the North Island, in company with an older man called Joe Graham. They walked from Southland to Lyttleton, crossed by ferry, and then walked from Wellington up through the Wairarapa, through the Manawatu Gorge, and across to the country south of Mount Ruapehu. Here he parted from Graham, who married a Maori woman, in a village named Ore Ore, near Raetihi; but later, after Graham had been denied ownership of her land, he shot her dead, and was then himself hacked to death with a cross-cut saw by his wife's sister. Meanwhile, Lee had partnered up with a young Maori, named only as Ned, and they wandered around in the virgin rainforest in the area between the upper Whanganui River and the Main Trunk railway line, before taking a punt down the river, and being caught by the police, for whisky-peddling and petty pilfering.

Intriguingly, Lee recalls in Delinquent Days, 'And yet later I wrote a third person account in at least two hundred pages about this walk and left it with a Nelson Street landlady who gave it to a young New Zealand journalist called John Mulgan, who boarded with her. When I read a book called Man Alone, years later, I knew that my story had coloured that depression-written book. ${ }^{35}$

Journal of New Zealand Studies NS13 (2012), 128-143. 
It included the grim events involving Graham, as Lee notes: 'All this story I wrote in the script that fell into the hands of the young journalist Mulgan' (87). The published work is then at least partly a later re-writing of a narrative of experiences that had first been written down much nearer in time to when they had happened.

There is a slight confusion here, in that John Mulgan, unlike his father Alan, was only ever an amateur or free-lance journalist, and never a full-time professional. ${ }^{36}$ One may wonder also whether it was John or his brother, David Kennaway Mulgan, who boarded in the Nelson Street house (with David somehow sending the manuscript on to John). Even so, this is gloriously suggestive, in terms of ways in which Mulgan's imagination may have been stimulated, to devise a rather different story for his protagonist Johnson, re-juggling the elements of the fugitive outlaw, the Maori wife, the fatal shooting, and the wanderings in the primeval forest.

Turning then to Man Alone, it can be seen that Mulgan has contrived a scenario whereby his character is forced into becoming a fugitive outlaw, and hiding out in the depths of the rain-forest, through a build-up of actions and conflicting motivations that have led on to his killing a man, however unintentionally. Whereas Lee, and his fictional alter ego Albany, had become outlaws because of their escapes from the oppressive Burnham regime, and their desire to remain free of it, Johnson becomes one because of the accidental shooting of the farmer Stenning, as an unintended consequence of his having had sex with this man's half-Māori wife Rua, on a farm somewhere west of Raetihi, and his desire to avoid the best remaining years of his life in gaol. He chooses to seek refuge from the forces of the law by hiding out in the depths of one of the most remote and extensive virgin forest areas then remaining in the North Island, the Kaimanawa Ranges. ${ }^{37}$ Johnson's eventual escape out of the country by ship may owe something to what Mulgan's father and others could have told him about the eventual escape by sea of the pre-war outlaw-fugitive Joseph Pawelka, who had achieved a kind of legendary stature, like to that of the latter-day serial escaper George Wilder. ${ }^{38}$

Paul Day in his literary biography of John Mulgan had viewed Mulgan's stimulus for writing Man Alone negatively, as a reaction against, and corrective to, his own father's falsifying sentimentalized writings about New Zealand. ${ }^{39}$ If instead one focuses on the possible imaginative influence of Lee's manuscript, this allows for a positive stimulus; and it places the imaginative centre of the novel not in the earlier chapters, but within those portraying Johnson's odyssey, following the death of Stenning, in sidling around the south-eastern slopes of Mount Ruapehu, crossing the Rangipo Desert and the tussock plateau, forcing his way into the heart of the Kaimanawas, and camping there for three long winter months, before making his way out towards the eastern side, and stumbling upon Bill Crawley's hut, when he is near to death from exhaustion and malnutrition. It is here that the mythic potency of the novel does indeed lie. Although Stuart Murray and Christina Stachurski in their discussions of this part of the novel both damage the cases they are trying to make, with geographical errors, and distorting ideological agendas, leading to critical overstatements and misreadings, they are at least concentrating on the most potent part of it, unlike Paul Day or, to a lesser degree, C. K. Stead. ${ }^{40}$

The 'Introduction' and 'Epilogue' frame the body of the novel as, ostensibly, a re-telling by an interlocutor of the story Johnson had told this person of his life experiences, from his first arrival in New Zealand through to his crossing the border into Spain to fight on the Republican side in the Civil War. It is then, despite being in the third person, implicitly Johnson's own story, 
reflecting his own point of view, mediated by that of this interlocutor as a more highly articulate and sophisticated narrator, who nonetheless retains a 'Hemingwayesque' low-keyness. ${ }^{41}$

Johnson, by the later stages of the novel, has the lineaments of the outlaw, rather than of a criminal, in that the circumstances of his killing minimize his culpability. He has been from its beginning an outsider, a rural-working-class Englishman, who has come out to a strange country alone and knowing no one. He has made just one close friend, 'Scotty', but then lost touch with him during the Queen Street Riot. He has come to value highly his independence, the freedom to work where and at what he chooses, and for only as long as he chooses, without accumulating property or domestic ties, although this kind of freedom has been severely curtailed by the onset of the Depression. He has also been set apart from most of humanity by the traumatic experiences as a World War One trench-warfare survivor, about which he remains reticent. He is depicted as an ordinary-looking, plain man and hence as a kind of every-man figure as war veteran (as a variant of Stead's notion). As Vincent O'Sullivan has recognized, a variant upon the veteran figures, in one case likewise named Johnson, in two of Mulgan's earlier poems. Despite this every-man quality he is denied, by his nationality, even the limited solidarity available to New Zealand returned servicemen. ${ }^{42}$

Still, as C.K. Stead has argued, '[a]s the novel advances he seems more and more the prototype Kiwi (or the fictional equivalent) - practical, inarticulate, unreflective, resourceful, unemotional, egalitarian, pragmatic', and 'in no passage' is he 'made to feel as deeply alien in New Zealand' as he does later, back in England on a Lincolnshire farm. ${ }^{43}$ The progress of his acculturation to New Zealand over about fourteen years is implied rather than articulated, although when times got hard the only ties he could fall back on were with men he had worked with. Escaped back to England, he has only one blood-relation to link up with, a brother, whose wife's hostility towards him deters any renewed bonding. Moreover, in the novel's second passage of extended cogitation, he finds in himself an incurable restlessness, and an inability to any longer fit in there: 'He himself could never live anywhere again. He had tried to live and settle and things had happened to him. Now he could not do that again'. ${ }^{44}$ In no longer being able to belong anywhere, to make any place his home, he can no longer have any secure nationality. We have already been told that he 'had changed his name by then', to elude police enquiries, 'and changed himself a good deal from the Johnson of other days', become 'a different man' from any one of his disparate former selves. ${ }^{45}$ This is a literary figure with no fixity. Having spent time alone, and without some sustainable defining occupation or context, he can find belonging, and escape from aloneness, only within a body of people moving along somewhere, 'doing something together'. 46

The life-situation that had brought about the killing, as Johnson later comes to understand, was the glum, slogging, stressful, trapped life of the grouchy Stenning, his moping, childless wife Rua, and Johnson as their farm-worker, stuck on a back-country farm in the depths of the depression, with farm-produce prices hopelessly low. 'It came with working away there on that farm, just the three of us, and no pay. None of us had any pay. You couldn't get away. You couldn't do anything but go on working . . . It wasn't any life. ${ }^{47}$ In reaction to this endless dreary toil, Rua and Johnson made love, half a dozen times, before Johnson's desire to avert trouble put a stop to their affair, yet trouble inexorably followed, with his efforts to get away precipitating the catastrophe he had sought to avoid. 
In a long sequence of thinking things through, veering between narration and indirect discourse, he is shown as working out 'that he would not stand well when it came to the law and the people who would judge him', and 'I won't stand well, he thought, with the people around here; there'll be no popularity wasted on me. ${ }^{48}$ Stenning had been a local; he was not; and even Rua and her whanau would be obliged to unite against him. Moreover, during his time since arriving in New Zealand, the one thing he had come to value most was freedom of choice of lifesituation, and he worked out that even a conviction for manslaughter rather than murder would lead to so many years in prison that he would end up 'too old to go away or to do anything with himself', hence that 'going away and escaping from it all was what he wanted to do', if he possibly could. ${ }^{49} \mathrm{He}$ made the choice then to become an outlaw, to take whatever slim chance this offered, setting aside civil bonds. Shown as neither a deep nor a quick thinker, and more inclined to be concerned with practical than with abstract issues, he is seen as arriving quite slowly at this basic decision, and then at a plan, and the practicalities of implementing it, with his thinking interwoven with narration of his activities, as he prepares to flee, packing up what he can carry, and then setting off.

All the rest of the original extent of the novel ('Part One') tells the story of the carrying out of his scheme, adapting to the circumstances he encountered. Its essence was in spending a sufficiently long period hiding away in a remote wilderness area for the vigilance of the authorities to have relaxed sufficiently to allow him to make his way to a port and slip out of the country. He decided that three months would be the right length of time, and that the Kaimanawa Ranges would serve his turn, and were reachable. He thought of it a 'game . . . a gamble', that 'would need not courage, but patience and endurance', and thereafter luck if he was to win it. ${ }^{50}$

For him, then, choosing to live as an outlaw meant choosing to endure several months of the most extreme aloneness. Forcing his way across to the edge of the ranges, and then through thick bush, over a ridge, and then down into a valley, where he found a suitable spot to camp, was not without difficulty and danger. Surviving there, in tough conditions, wholly dependent for food upon the wekas and kereru (wood-pigeons) he succeeded in shooting with his .22 rifle, required fierce self-discipline ( since he could only afford to use two bullets a day, and if he missed one shot, had even less to eat), and mental stability. This episode is delineated in just four paragraphs, dealing with the practicalities of coping and then with his changing mental state: after weeks in the depths of the forest; there, 'he felt within himself a great solitude, a feeling that had never troubled him before in the long periods of his life that he had spent alone. ${ }^{51}$ Lassitude, force of habit, and weakness due to semi-malnutrition, combined to tempt him to stay put, and inevitably perish there. It took a sudden 'fury with himself' to force him into motion again, to make his way down the river and out towards the eastern side of the forest. ${ }^{52}$

This took 'weeks', and by the time he stumbled upon Bill Crawley's hut he was exhausted, starving, half-naked, and wearing out the last shreds of his will-power. He has lost the gun that had given him power to feed himself in the harsh winter rain-forest. Luckily, he encountered there an Irishman with a soft spot for outlaws, an ally who would enable him to recover, and in due course set him on the next stage of his journeying. Unluckily, on his way to Auckland, he would be recognized in Hamilton, and narrative tension is heightened, making it hard, though not impossibly hard, for him to slip onto a ship and escape from the country. In this he found help with another ally, a retired scow captain he had once worked for. Had he been entirely a 'man 
alone', he would have had 'no bloody chance. ${ }^{53}$ With allies, he could seek other ways of living.

As an outlaw, he is given some claim to readers' sympathy. Still, it is made clear that, thereafter, he would be obliged to spend the rest of his life in grey areas, living in ambiguous situations under an assumed name. Nonetheless, with the imminent onset of the Second World War, which John Mulgan foresaw, and foreshadowed in his novel, the rule of law would for the meantime lose much of its force, and a man 'you can't kill' could doubtless get by. ${ }^{54}$ Like Albany Porcello at the end of The Hunted, he will remain an outlaw, shrewdly cautious, yet not manifestly inwardly troubled, as Albany is, by feelings of insecurity, anxiety and fear. He has after all endured 'worse things'. 55

One can say further that the three works have three features in common. The first is that they diverge strikingly from the typical colonial narrative, in which individuals from relatively well-todo backgrounds have to 'rough it', toil hard, endure sundry vicissitudes, for a decade or so, yet eventually 'make it', arriving at some degree of prosperity, whilst securing bonds of family and community. Here, the protagonists are not merely lower-class males but also not upwardly mobile, and their lives remain hard. Lee had acknowledged what a revelation Upton Sinclair's The Jungle had been to him, with its demonstration that fiction could be written about such people, including a hero he could identify with. ${ }^{56}$ For these characters, it is a minimally satisfactory ending that they survive, and are out of immediate danger.

The local cultural momentum that had built up during the first decade of the century had been wrecked by the onset of the 1914-18 war, so that writers in the 1920s and 1930s were denied the literary models and contexts they might have had. For Hyde, as for Sargeson in this era, it was a serious challenge to find New Zealand stories, and a voice in which to tell them; and Starkie as a 'queer bird' gave her both an authentic story and a voice. ${ }^{57}$ John A. Lee found his story in his own extraordinary life-story. John Mulgan manifestly found the key elements for the heart of his story in the Lee manuscript that came into his possession, of which Lee's Delinquent Days is in part a rewriting, again an authentic New Zealand story.

Secondly, for each of their protagonists the primary imperative is survival, yet not simply biological, but of their freedom of spirit, and for that they take serious risks. They also have to endure the stress of isolatation and spend time in a state of outlawry, which can be hard enough from day to day, and sometimes exceedingly hard. Starkie survives trench warfare at Gallipoli and the Western Front, the Le Havre gaol, his period on the run in France, and his near-fatal wounding, by virtue not only of his extraordinary degrees of physical and mental toughness, and animal cunning, but also of a fierce will to live. Alex Calder has written of his 'reckless rage' and of his 'spin[ning] out of control', and going 'berserk', after the deaths of the young Jackie Mackenzie in July and of his brother in September 1916; and yet in practice he remains effective as a vengeful killer, in these episodes, and survives them, precisely because he retains enough animal cunning, instead of going completely wild. ${ }^{58}$ Still, in battle, he has his fellow soldiers share the same dangers. It is as a lone outlaw, making his escape from the Le Havre military prison, risking being shot by guards, or drowning, that his psychological survival is most at stake.

Lee's Albany is only a teenager, and the perils he risks with his quests for freedom are simply harsh floggings and other punishments, yet he persists with them. Alongside developing impressive survival skills, he hones his abilities to know when to accept temporary defeats, endure punishment, and plan the next venture. Johnson's three months' hiding away in a remote 
river-valley, and his weeks-long struggle to make his way out to the far side, represent no sort of heroic frontier-crossing or mountaineering ascent, as Stuart Murray has indicated with his claims for contemporary British literary precedents, nor a masculinist 'completion of the colonial project' of 'conquest and control', as Christina Stachurski has argued, but rather, simply, the accomplishment of survival, by the narrowest of margins, by an unusually sturdy and resilient man. ${ }^{59}$ Still, like Starkie, he risks physical survival to preserve his freedom of spirit.

Lastly, there is the dimension of the outlaw character as 'man alone' (or, in Albany's case, 'boy alone'), whether geographically or psychologically isolated, alienated, and excluded or selfexcluded from social bondings. Given that the figure of the 'man alone' (or 'woman alone') has been widely recognized as a potent topos for our nation's literature, the sub-set of men alone as outlaws carries a part of this potency. ${ }^{60}$ Within the three narratives addressed, neither aloneness nor outlawry is a constant: the central character becomes most fully alone, and most an outlaw, only in an extreme situation; otherwise he becomes more or less alone, more or less of an outlaw. Acts that can be perceived as in some degree criminal in these works serve simply as the occasion or trigger for the move into a state of outlawry, which is dramatized with shifts into the character's centre of consciousness. In relation to the monstrous crime against humanity that was the First World War, and the brutality of military authority, Starkie's offences against good order and discipline seem negligible, whereas his exploits both as a fighting soldier and as a defiantly lone outlaw give him a kind of charismatic stature. Albany's story of defiance of a disproportionately punitive regime, and of his experiences as a hunted fugitive, attains its liveliest entry into his consciousness during the episode in which he manages to remain at liberty for a whole month, alone. For Johnson, whereas his earlier New Zealand experiences have interest in themselves, it is as 'man alone' in the most extreme sense, as the lone outlaw sustaining his life and liberty of spirit in the wilderness, that he attains iconic stature.

That the figure of the lone outlaw should have had a strong appeal to writers and readers in context of the 1930s depression can be seen as having much to do with a profound loss of faith in the hitherto assumed benignity of the establishment, such as there was of it in New Zealand, towards the 'common man' (or, woman), and in the hitherto supposed benignity of the so-called 'Mother Country' towards its fledgling Dominions. Their perceived brutality and callous indifference to hardship, in a context of widespread loss of supposedly secure employment, shattered the normal comfort-zone of the haves, encouraging an extending of imaginative sympathy to an increased proportion of have-nots. The individual then who rejects establishment bonds and mores and gets away with it can take on hero status as one who rejects victimhood and achieves a kind of triumph simply by surviving.

\footnotetext{
${ }^{1}$ This paper arose out of work for the chapters I contributed to a broader study - The Lonely and the Alone: The Poetics of Isolation in New Zealand Fiction, Amsterdam; New York, 2011 - written in collaboration with Doreen D'Cruz. It has been substantially revised and expanded in response to questions asked at the 'Man Alone' Conference, and to readers' reports. The writing of these chapters, and of this paper, preceded the launch of Alex Calder's The Settler's Plot: How Stories Take Place in New Zealand, Auckland, 2011, and any encounter with his chapter, 'Violence and the Psychology of Recklessness: Robin Hyde's Passport to Hell', in Mary Edmond-Paul, ed., Lighted Windows: Critical Essays on Robin Hyde, Dunedin, 2008, pp.67-72, hence any similar insights were arrived at independently.
} 
${ }^{2}$ Derek Challis, Gloria Rawlinson, The Book of Iris: A Life of Robin Hyde, Auckland, 2002, pp. 269-71, 303-4, 31923, 341-2, 345, 358-9, 375, 395-6, 413-4, 666-7, 672-4, 687-9, 695-6, 715-6, 727-8. Hyde's review appeared in the New Zealand Observer, 31 January 1935. Charles Brasch noticed the novels' being of a 'kind', although Man Alone 'was by far the best of its kind'; see Indirections: A Memoir 1909-1947, Wellington; Oxford; New York, 1980, p.362.

${ }^{3}$ James Cowan, The Adventures of Kimble Bent: A Story of Wild Life in the New Zealand Bush, London; Melbourne; Christchurch; Wellington; Dunedin, 1911, pp.7-8, 13-14, 18-21, 61, 260-61, 281-90, and passim. Cowan tells more about his conversations with Bent in Tales of the Maori, Wellington, 1982, pp.124-8. See also Cowan, The New Zealand Wars: A History of the Maori Campaigns and the Pioneering Period, Wellington, 1983Volume 2, pp.14-15, 57, 66, 145, 183-4, 190, 205, 209, 217-19, 262n, 291, 294, 296, 303. In practice, Bent became subject to Māori customary law, rather than outside any law.

${ }^{4}$ Michael King, The Penguin History of New Zealand, Auckland, 2003, pp.345-9, 306-12. For conditions in the 1930s depression, and the demonstrations and riots, see Tony Simpson, The Sugarbag Years, Wellington, 1974, esp. pp.112-33.

${ }^{5}$ 'Crime Sheet' is the title of Hyde's handwritten notes. Her typescript draft has 'Bronze Outlaw: A New Zealand Soldier's Story' (see Robin Hyde, Passport to Hell: The Story of James Douglas Stark, Bomber, Fifth Reinforcement, New Zealand Expeditionary Forces, ed. and intro. D.I.B. Smith, Auckland, 1986, p.213). The original publisher, Denis Archer, considered 'Bronze Outlaw' 'too suggestive of a "Western"' and settled on Passport to Hell, which was, and remained, the title for ch.13, in which Stark is consigned to the Le Havre military prison. See Challis, Rawlinson, The Book of Iris, p.282.

${ }^{6}$ On 2 June 1933 Robin Hyde had had a depressive breakdown and tried to commit suicide by drowning, leading to consignment to a cell in the Auckland Public Hospital, and then, on 20 June, to the Auckland Mental Hospital at Avondale, where she went to The Lodge, otherwise Grey Lodge, 'a residential clinic for convalescent patients and patients who had experienced nervous breakdowns', Challis, Rawlinson, pp.214-18. As her condition improved, she lived more freely outside of The Lodge, though she returned to it through to late 1936. She subsequently revisited it intermittently as her Auckland base. Her consciousness of her psychological fragility comes through strongly in her journal and other writings; see Robin Hyde, Your Unselfish Kindness: Robin Hyde's Autobiographical Writings, ed. Mary Edmond-Paul, Dunedin, 2011, esp. pp.208-15, 225-34, 242-3, 298-306.

${ }^{7}$ Ibid., p. 217.

${ }^{8}$ Hyde, p.xx.

${ }^{9}$ Hyde gives his date of birth as 'July $4^{\text {th }}, 1898$ ' and his age in 1913 as 'nearing the end of his fifteenth year'; and Stark himself 'always insisted that he was born in 1898.' However, the Register of Births, Deaths and Marriages, Invercargill, gives the date of birth of 'John Douglas Stark' as 17 July 1894. Hence when he enlisted in 1914 he was twenty, rather than a youth of sixteen $(12,33$ Hyde, pp.xvi, 12, 33, 217, 219. Oddly, the record of his burial at the Waikumete Cemetery, Auckland, gives his name as James Douglas Stark, his date of death as 22 February 1942, and his age at death as forty-five, whereas the register of deaths lists him as 'John Douglas Stark', dying in Auckland in 1942, with his age again given as forty-five (he would have been forty-seven). His death is said to have come about through medical complications resulting from his lung wound; like so many other war-veterans he did not make old bones.

${ }^{10}$ Hyde, Passport, pp.xix-x.

${ }^{11}$ Ibid., pp.xxvii-xviii. Hyde defended Passport to Hell against a critic of its factual accuracy on these grounds (letter, Southland Times, 10 October 1936). Smith in his introduction and notes acknowledges that Hyde has been selective, in that some happenings recorded in her typescript notes do not appear at all in the book as published, or else are altered, and that in certain places 'she darkens the portrait a little', pp.xi-xii, xiv-xx, 219, 239-42).

${ }^{12}$ Hyde, Passport, p.10.

${ }^{13}$ Ibid., pp.10-11.

${ }^{14}$ Ibid. D.I.B. Smith notes that "Delaware" was the English name for the Leni or Lenape, a tribe of North American Indians of Alonquian stock settled on the banks of the Delaware; they were pushed westward by Europeans and in 1789 were placed on a reservation in Ohio.' If they were associated with a lake, it was very remote from the one now officially known as Great Bear Lake, in the far northwest of Canada, and also from Florida, where Starkie's father was born, according to his obituary in the Southland Daily Times (5 November 1910). Wyald's father had been an 
American Army officer, presumably white, and his mother Indian. Hyde's account of Wyald Stark's family is not entirely accurate. His second wife's name was Florence, née Evans, not Anita. They married in 1885, after his first wife Elizabeth died on 6 July 1883. From the first marriage there was one surviving daughter, Amelia, who married William Adcock on 31 October 1881; there was no other daughter called Rose. Starkie's two older brothers were Arthur Wyald Stark (born 1886) and George Singleton Stark (born 1890, killed at the Somme 15 September 1916) (Register of Births, Deaths and Marriages, on microfiche); see Hyde, Passport, pp.216-18.

${ }^{15}$ Ibid., p.15.

${ }^{16}$ Ibid.,

${ }^{17}$ Ibid., pp.17-18.

${ }^{18}$ Ibid., p.58.

${ }^{19}$ Ibid., p.60.

${ }^{20}$ Ibid., pp.154, 161, 163-164, 167.

${ }^{21}$ Ibid., pp.163-4, 167, 176.

${ }^{22}$ Fourth Company, First Battalion, Otago Regiment. Stark rejoined them in February 1918, and over 22-26 March the New Zealand Division moved fast to fill a gap in the line during Ludendorff's Michael Offensive, to the east of Amiens, and succeeded in closing it, and holding their new line under heavy attacks, which ended after 5 April, although artillery bombardments and raids continued. First Battalion Otago took over the holding of part of this line, in the La Signy Farm sector, on 1 June 1918, and Stark's duel with the sniper occurred a few days later. 'Frequent daylight reconnaissances of the enemy's lines were being carried out by Pte. Stark, until when single-handed he rushed an enemy post near La Signy Farm and was grievously wounded; his adventurous career thus abruptly terminating for a time at least'. A. E. Byrne, Official History of the Otago Regiment, N.Z.E.F. in the Great War 1914$18,2^{\text {nd }}$ ed, Dunedin, 1921, p.298.

${ }^{23}$ Hyde, Passport, pp.170, 182.

${ }^{24}$ Ibid., p.183.

${ }^{25}$ Ibid., p.238.

${ }^{26}$ Ibid., p. 184 .

${ }^{27}$ Ibid., p.198.

${ }^{28}$ Hyde, Your Unselfish Kindness, p.245. The 1935 Journal, entry is dated 12 May.

${ }^{29}$ Challis, Rawlinson, p.342. Hyde had completed writing her book in April 1935, and was notified of its acceptance by Archer in November; it was issued in England in April 1936, and copies arrived in New Zealand in May. Challis, Rawlinson, pp.282, 306, 340, 344-5.

${ }^{30}$ Janet Frame, The Envoy from Mirror City: An Autobiography: Volume Three, Auckland, 1986, pp.140-1, 175-6. Lee's brief account of his earlier experiences in Simple on a Soap-Box, London, 1964, pp.13-20, differs in detail from Porcello's in The Hunted, which are given narrative shaping. Lee himself, after being sent out to work for an obnoxious grocer, and being returned to the Burnham Industrial School by train, changed trains, and enjoyed an interlude of freedom, yet was caught, sent back to the School, and flogged (once again). His further attempts to escape from its authority eventually succeeded, and he spent several years as a casual worker and vagabond. In the novel, Porcello's escape during this return-journey, by changing trains, is wholly successful, although it leads on to the uneasy life of the outlaw. Erik Olssen's biography, John A. Lee, Dunedin, 1977, deals relatively briefly with this part of Lee's life, and with his fictional treatments of it, and is principally concerned with his career as a Labour Member of Parliament, and later life.

${ }^{31}$ John A. Lee, The Hunted, Wellington, 1975, p.13.

${ }^{32}$ Ibid., p. 169.

${ }^{33}$ Ibid., pp.256-6.

${ }^{34}$ Ibid., p.7.

${ }^{35}$ John A. Lee, Delinquent Days, Auckland; London, 1967, p.85.

${ }^{36}$ As a student at Auckland University, John Mulgan wrote articles and editorials for the student newspaper Craccum, becoming its editor at the start of 1932, and articles and poems for the annual magazine Kiwi. While in Oxford, employed as an editor by the Oxford University Press, in 1936-7 he alternated with the journalist Geoffrey Cox in writing a fortnightly column, 'Behind the Cables', about European affairs for the Auckland Star and other 
New Zealand newspapers. Vincent O'Sullivan, Long Journey to the Border: A Life of John Mulgan, Auckland, 2003, pp.61, 65, 67-68, 72-5, 81, 161-2, 189.

${ }^{37}$ Rod Orange, 'Johnson Goes Bush: Geography and Fiction in Man Alone', Kōtare: New Zealand Notes \& Queries, 5, 1 (2004), seen online (NZETC).

${ }^{38}$ John D. Wills, 'Pawelka, Joseph John Thomas 1887- ?: Criminal, prison escaper', in The Dictionary of New Zealand Biography, Volume Three, 1901-20, Auckland; Wellington, 2000, pp.392-3.

${ }^{39}$ P. W. Day, John Mulgan, New York, 1968, pp.83-9, 97.

${ }^{40}$ Stuart Murray, Never a Soul at Home: New Zealand Literary Nationalism and the 1930s, Wellington, 1998, pp.213-9, links Johnson's journey to contemporary English literary precedents in frontier-crossing and mountainascending motifs. Christina Stachurski, Reading Pakeha? Fiction and Identity in Aotearoa New Zealand, Amsterdam; New York, 2009, pp.13-17, 34, views it in terms of the completing of the male colonialist conquest of the land, rather than of the hiding-out of the fugitive outlaw. C. K. Stead, In the Glass Case: Essays on New Zealand Literature Auckland, 1981, pp.79, 83-4, focuses mainly on the first part of the narrative, seeing it in Marxist terms, but thereafter seeing Johnson as an every-man figure.

${ }^{41}$ Mulgan deplored his novel's being 'one of these sordid Hemingwayesque sort of books', O'Sullivan, p.191; yet in practice, as Charles Brasch observed, 'the style carried one along, although it would only do for that kind of novel', Indirections, p.362.

${ }^{42}$ O'Sullivan, pp.115, 137-8. Mulgan himself, in Report on Experience (written in 1945; published posthumously, London, 1947), observed how pervasively his generation was haunted by 'the shadow of that earlier war' (p.33). Patrick Evans, The Penguin History of New Zealand Literature, Auckland, 1990, discussed the widespread presence in the novel of warfare terms and images, pp.124-9. Lawrence Jones, Picking Up the Traces: The Making a New Zealand Literary Culture 1932-45, Wellington, 2003, discusses briefly this aspect of the novel, p.358. For Johnson's not belonging, see John Mulgan, Man Alone, Hamilton, 1960, pp.9-10.

${ }^{43}$ Stead, 'John Mulgan: A Question of Identity', pp.84-5.

${ }^{44}$ Mulgan, p.196.

${ }^{45}$ Ibid., p. 189.

${ }^{46}$ Ibid., p.205.

${ }^{47}$ Ibid., p. 182.

${ }^{48}$ Ibid., p.126.

${ }^{49}$ Ibid., pp.126-7.

${ }^{50}$ Ibid., p. 130.

${ }^{51}$ Ibid., p.141.

${ }^{52}$ Ibid., p.142.

${ }^{53}$ Consider the dying utterance by Harry Morgan, in Ernest Hemingway's To Have and Have Not (1937): 'No matter how a man alone ain't got no bloody chance' (so, in the British edition), from which the novel's title was chosen (O’Sullivan, pp.191-2).

${ }_{55}^{54}$ Mulgan, p.207.

${ }^{55}$ Ibid., p.6.

${ }^{56}$ John A. Lee, Simple on a Soap-Box, pp.17-18. Olssen, John A. Lee, p.9.

${ }^{57}$ Challis, Rawlinson, pp.271-7.

${ }^{58}$ Alex Calder, The Settler's Plot, pp.197-9, 202-3.

${ }^{59}$ Murray, Never a Soul at Home, pp.212-5, where he envisages Johnson making an ascent of Mount Ruapehu rather than simply sidling around its lower southern slopes on his way to somewhere else. Christina Stachurski, Reading Pakeha?, pp.13-17, 34 .

${ }^{60}$ Lawrence Jones, 'The Novel', in Terry Sturm, ed., The Oxford History of New Zealand Literature in English, $2^{\text {nd }}$ ed, Auckland, 1998, pp.157-9, 162-3, 166-8, 184, 202-7, 223. Jones, in Roger Robinson, ed., The Oxford Companion to New Zealand Literature, Nelson; Auckland, 1998, pp.331-2. 